\title{
The Role of Macrophages in the Host's Defense against Sporothrix schenckii
}

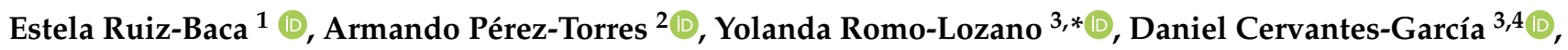 \\ Carlos A. Alba-Fierro ${ }^{1}$, Javier Ventura-Juárez ${ }^{3}$ (D) and Conchita Torriello ${ }^{2}$ \\ 1 Facultad de Ciencias Químicas, Universidad Juárez del Estado de Durango, Av. Veterinaria S/N, \\ Durango 34120, Mexico; eruiz@ujed.mx (E.R.-B.); carlos.alba@ujed.mx (C.A.A.-F.) \\ 2 Facultad de Medicina, Universidad Nacional Autónoma de México, Ciudad de Mexico 04510, Mexico; \\ armandop@unam.mx (A.P.-T.); toriello@unam.mx (C.T.) \\ 3 Centro de Ciencias Básicas, Universidad Autónoma de Aguascalientes, Av. Universidad No. 940, \\ Aguascalientes 20100, Mexico; dcervantesga@conacyt.mx (D.C.-G.); jventur@correo.uaa.mx (J.V.-J.) \\ 4 Consejo Nacional de Ciencia y Tecnología, Ciudad de México 03940, Mexico \\ * Correspondence: yromo@correo.uaa.mx
}

Citation: Ruiz-Baca, E.; Pérez-Torres,

A.; Romo-Lozano, Y.; Cervantes-García,

D.; Alba-Fierro, C.A.; Ventura-Juárez, J.

Toriello, C. The Role of Macrophages in the Host's Defense against Sporothrix schenckii. Pathogens 2021, 10, 905. https://doi.org/10.3390/ pathogens 10070905

Academic Editor: Elena De Carolis

Received: 24 May 2021

Accepted: 14 July 2021

Published: 18 July 2021

Publisher's Note: MDPI stays neutral with regard to jurisdictional claims in published maps and institutional affiliations.

Copyright: (c) 2021 by the authors. Licensee MDPI, Basel, Switzerland. This article is an open access article distributed under the terms and conditions of the Creative Commons Attribution (CC BY) license (https:// creativecommons.org/licenses/by/ $4.0 /)$.

\begin{abstract}
The role of immune cells associated with sporotrichosis caused by Sporothrix schenckii is not yet fully clarified. Macrophages through pattern recognition receptors (PRRs) can recognize pathogen-associated molecular patterns (PAMPs) of Sporothrix, engulf it, activate respiratory burst, and secrete pro-inflammatory or anti-inflammatory biological mediators to control infection. It is important to consider that the characteristics associated with $S$. schenckii and/or the host may influence macrophage polarization (M1/M2), cell recruitment, and the type of immune response (1, 2 , and 17). Currently, with the use of new monocyte-macrophage cell lines, it is possible to evaluate different host-pathogen interaction processes, which allows for the proposal of new mechanisms in human sporotrichosis. Therefore, in order to contribute to the understanding of these host-pathogen interactions, the aim of this review is to summarize and discuss the immune responses induced by macrophage-S. schenckii interactions, as well as the PRRs and PAMPs involved during the recognition of $S$. schenckii that favor the immune evasion by the fungus.
\end{abstract}

Keywords: sporotrichosis; phagocytosis; immune response; virulence factors; dermal resident macrophages

\section{Introduction}

Sporotrichosis is a subcutaneous mycosis frequently found in tropical and sub-tropical areas of Latin America and other countries throughout the world [1-3]. Its etiological agent, Sporothrix schenckii, was considered to be a unique species for almost a century. Currently, there are other Sporothrix species with significant importance in medical mycology, such as S. brasiliensis, S. globosa, S. luriei, S. mexicana, and S. pallida, all identified and classified by molecular biology techniques [4], mainly by those methods based on the detection of the calmodulin gene or the nuclear ribosomal internal transcribed spacer (ITS) region [5].

All species of Sporothrix are thermodimorphic fungi, presenting the filamentous saprophytic morphotype in soil, plants, and animal excreta or in vitro at $25^{\circ} \mathrm{C}$, and yeast parasitic morphotye in tissue host or in vitro at $35-37^{\circ} \mathrm{C}$. As in other subcutaneous mycoses, host infection occurs by traumatic inoculation through the skin of materials contaminated with fragments of hyphae or conidia of the fungus. Rarely, this infection is acquired by spore inhalation leading to a primary lung disease [4,6].

The fixed and lymphocutaneous lesions that involve skin and subcutaneous tissues are the most common clinical forms of sporotrichosis [7], and usually affect immunocompetent hosts. On the other hand, disseminated presentations, such as disseminated cutaneous, with or without visceral, osteoarticular, and pulmonary involvement, are more frequent in 
immunosuppressed patients [2]. In the majority of cases, treatment becomes imperative and, as an exception, spontaneous resolution occurs. The increased clinical severity is related to a decrease in the host's immune and inflammatory responses, the clinical form of the disease, the species of Sporothrix involved, heavy fungal burden, and extensive dissemination $[2,4,6,8]$.

The innate immune system is the host's first line of defense against pathogens. Generally, this immune response is efficient and capable of controlling the infection without disease development, mainly in opportunistic infections. However, in immunocompromised hosts, pathogens can proliferate and establish the disease [9]. Surveillance and clearance of fungal pathogens are highly dependent on the phagocytic activity of macrophages and neutrophils $[10,11]$. The efficiency by which phagocytes recognize, internalize, and kill fungal pathogens depends on the size, shape, and composition of the fungal cells and the success or failure of various fungal immune evasion mechanisms [12]. Responses may also depend on the host's species or model in which the macrophage-S. schenckii interactions are studied [13].

The fungal cell wall (CW) is the first point of contact between the host and the pathogen, consequently playing an important role in pathogenesis and immunogenicity, the latter considering that many $\mathrm{CW}$ components have been characterized as inducers of cellular and humoral immune response [14]. Changes in composition and/or structure in CW that occur over time in Sporothrix yeast cultures influence their recognition and phagocytosis by human monocyte-derived macrophages [15] or by murine macrophages [16], and cytokine secretion by human peripheral blood mononuclear cells (PBMCs) [17].

The key role of macrophages as innate immune response cells depends on the expression of surface receptors, which can be activated by factors derived from the host and pathogens [18]. A comprehensive analysis of the molecular factors of $S$. schenckii that activates receptors over the surface of macrophages has been performed by Alba-Fierro et al. [19]. This review tries to explain how the immune response induced by the fungus relies on the activated signaling pathway, the nature of the antigen, and the morphology of the fungus. These phagocytic cells are able to act as reservoirs for the immune evasion of intracellular pathogens and as triggers of specific immune responses mediated by antigen presentation and proinflammatory cytokines and chemokines secretion [20]. In this review, we will discuss the role of macrophages in the host's defense against $S$. schenckii and the strategies used by the fungus for immune evasion.

\section{Macrophages: A Brief Overview}

Macrophages constitute a ubiquitous mononuclear phagocyte system (MPS) that is adaptable, regulated, and able to evoke defense responses, locally and systemically. The heterogeneous functions of macrophages are maintained through a fine regulation. To protect the host, the activities of macrophages (phagocytosis, oxidative burst, clearance, and cytokine secretion) contribute to the activation of innate and adaptive immune responses (afferent and efferent arms of the immune system, respectively) to control the infection, supporting the inflammatory reaction [21]. In a tissue injury, a similar process is activated but triggered by different molecular signals, allowing tissue repair [22].

Macrophages share the common origin from hemopoietic stem cells to monocytes, dendritic cells (DC), and osteoclasts [23-25]. However, they display considerable heterogeneity, differing widely in phenotype and morphological appearance, depending on their location [26,27]. Resident macrophages have a dual origin: (1) macrophages derived from erythromyeloid precursors (yolk sac and fetal liver precursors) and seeded throughout tissues, persisting in adults as resident self-maintaining populations, which perform phagocytic and organ-specific trophic functions [28,29]; and (2) bone marrow-derived blood monocytes that replenish resident macrophages, mainly following injury, infection, and sterile inflammation. Therefore, different tissues and host locations contain variable mixtures of embryonic origin and bone marrow-derived monocytes/macrophages. This 
dual origin determines the differences in the biosynthetic responses to endogenous and exogenous stimuli and a marked phenotypic heterogeneity [30].

Monocytes and macrophages express a wide range of molecules for the recognition and intake of self-derived, foreign particles and molecules by phagocytosis and endocytosis, respectively. Many of their secretory activities, including pro- and anti-inflammatory cytokines, proteases, chemokines, growth and differentiation factors, reactive oxygen species (ROS), and also reactive nitrogen species (RNS), are induced in response to microorganisms activating changes in gene expression [31]. In addition, macrophages are activated and differentiated by cytokines secreted from lymphocytes and other local tissue cells, and this activation gives them the capacity to respond to diverse challenges [32].

\subsection{Macrophage Subtypes}

Macrophages are involved in the homeostatic functions of organs, development, and tissue repair as well as in the defense against pathogens, chronic inflammation, fibrosis, and cancer [33]. Macrophages are not homogeneous, and their phenotypic heterogeneity correlates with unique functions and specificity to local microenvironments, enabling a plasticity to produce appropriate responses to pathogens or to signal molecules released by activated lymphocytes or damaged tissue. This heterogeneity is referred, mainly but not exclusively, to as polarization, which subdivides macrophages in terms of their activation as 'classical' (Th1/M1-type), or 'alternative' (Th2/M2-type) [21,34].

At the same time, subsets of blood monocytes in humans, mice, and other species with phenotypic differences and heterogeneity in their origin, maturation, and activation have been identified [27]. Human monocytes are divided into subsets based on surface $\mathrm{CD} 14$ and $\mathrm{CD} 16$ expression. $\mathrm{CD} 14^{++} \mathrm{CD} 16^{-}$, named classical monocytes, are the most prevalent monocyte subsets in human blood, and, similarly to mice monocytes Ly6 $\mathrm{C}^{h i}$, these cells express the chemokine receptors CCR1 and CCR2. The CD16 ${ }^{+}$population is composed of two subsets, $\mathrm{CD} 14^{+} \mathrm{CD} 16^{++}$and $\mathrm{CD} 14^{++} \mathrm{CD} 16^{+}$monocytes (non-classical and intermediate monocytes, respectively). The $\mathrm{CD} 14^{+} \mathrm{CD} 16^{++}$subset (patrolling) is similar to the mice Ly6C low monocytes population [35-37].

\subsubsection{M1 Classical Monocytes (Inflammatory)}

Classically activated M1 macrophages are responsible for the type 1 immune response, which is mainly formed by cytokines like interferon (IFN)- $\gamma$ and tumor necrosis factor (TNF)- $\alpha$, and induced by lipopolysaccharide (LPS)-bacterial related components and TLR analogs. These macrophages show higher antimicrobial capacity and are prototypical cells that produce pro-inflammatory mediators [38]; in addition, they are efficient in the generation of ROS, pro-inflammatory cytokines (interleukin (IL)- $1 \beta$, TNF- $\alpha$ and IL-6), and cytotoxicity (phagocytosis of microorganisms and necrotic cells). These M1 monocytes are important in the innate immune protection against infectious pathogens. During an infectious challenge, M1 monocytes upregulate TNF- $\alpha$, which activates inducible nitric oxide synthase (iNOS)-producing-DC known as TNF/iNOS-producing (Tip)-DC, which contributes to the development of adaptive immune responses. In mice, M1 macrophage-associated markers include IL-12, major histocompatibility complex (MHC) class II molecules, and iNOS $[37,39]$.

\subsubsection{M2 Non-Classical Monocytes (Patrolling, Anti-Inflammatory)}

Anti-inflammatory or alternatively activated M2 macrophages represent the promotion of type 2 immune response as its differentiation can be mediated by IL-4, mainly released from basophils and mast cells [32]. Significantly, these cells can produce IL-4 in response to chitin from fungi [40]. M2 macrophages have been shown to trigger the deposition of extracellular matrix proteins as arginase activity is induced by IL-4, and collagen production is facilitated by the conversion of arginine to ornithine [41]. It is known that signal molecules such as signal transducer and activator of transcription (Stat)1, Stat3, Stat6; suppressor of cytokine signaling (SOCS)-1; interferon regulatory factor (IRF)-4, 
as well as that a variety of miRNAs are involved in the macrophage polarization regulation. On the other hand, the expression levels or activity of the transforming growth factor (TGF)- $\beta$, IL-4, IL-10, and Stat3 are clearly elevated in M2 macrophages, so they are linked to anti-inflammatory actions and tissue repair [42,43]. There is evidence that these cells are derived from classical monocytes which can give rise to tissue-resident macrophages responsible for tissue healing promotion [44].

\subsection{Macrophages Recruitment}

During both homeostasis and inflammation, circulating monocytes leave the bloodstream and migrate into tissues where they are subdivided into subsets that differ in size, trafficking, innate immune receptor expression, and their ability to differentiate. Following stimulation with pro-inflammatory cytokines and/or microbial molecules or local growth factors, these cells differentiate into macrophage or DC populations [45]. Recruitment of monocytes is essential for an effective control and clearance of viral, bacterial, fungal, and protozoal infections, but recruited monocytes could also contribute to the pathogenesis of inflammatory and degenerative diseases [46].

\subsection{Phagocytosis}

The process of engulfment and destruction of invading microorganisms is called phagocytosis and is a critical part of the innate immune response. In addition, clearance of apoptotic bodies occurs through this process, an essential aspect of tissue homeostasis and remodeling [47]. Phagocytosis in macrophages is mediated by a broad range of receptors through their interactions with natural and altered self-components as well as by several microorganisms that trigger signaling events for actin-dependent particle internalization. Examples of receptors related to phagocytosis are class A (macrophage receptor with collagenous structure receptor-MARCO), B (CD36 receptor), D (CD68 receptor), scavenger receptor (SR) [48], mannose receptor (MR, CD206), Dectin-1 (CLEC7A) [49], complement$3(\mathrm{CD} 11 \mathrm{~b} / \mathrm{CD} 18)$ receptor, $\mathrm{F}_{\mathrm{c} \gamma}$ receptors $\left(\mathrm{F}_{\mathrm{C} \gamma \mathrm{R})}\right.$ ), and DC-specific intercellular adhesion molecule-3-grabbing non-integrin (DC-SIGN, CD209) [47,50].

Receptor engagement around the entire particle appears to be required for the completion of the internalization process in all instances, culminating in the formation of a membrane-bound vesicle termed phagosome. Then, phagosomes need to be converted into a potent microbicidal organelle that is central for both innate and adaptive immunity. This process, termed phagosome maturation, occurs through the fusion of lysosomes, converting them into phagolysosomes that are more acidic ( $\mathrm{pH}$ 5.5-6.0) and, thus, acquire microbicidal and degradative organelle properties. In this subcellular compartment, the digestion of proteins, lipids, and carbohydrates is mediated by the concerted action of proteases, lipases, nucleases, glycosidases, and phosphatases, mediating the complete disintegration of large complex structures, such as dead or dying microbes [47,50,51]. ROS production, during the respiratory burst of phagocytes, is important for the innate immune response. The enzyme complex nicotinamide adenine dinucleotide phosphate (NADPH) oxidase, which constitutes one of the most important sources of ROS, is responsible for the electron transfer from NADPH to $\mathrm{O}_{2}$ and the simultaneous production of the superoxide anion $\left(\mathrm{O}_{2}^{-}\right)$. The superoxide dismutase can dismutate $\mathrm{O}_{2}^{-}$to hydrogen peroxide $\left(\mathrm{H}_{2} \mathrm{O}_{2}\right)$, and then other molecules can be produced such as hydroxyl radicals $\left(\mathrm{OH}^{-}\right)$and singlet oxygen $\left({ }^{1} \mathrm{O}_{2}\right)$. It is important to mention that myeloperoxidase, one of the main components of primary or azurophilic granules, can use $\mathrm{H}_{2} \mathrm{O}_{2}$ to oxidize halides into more toxic reactive compounds such as hypochlorous acid $(\mathrm{OHCl})$ and chloramines [49].

Like ROS, RNS are important for pathogen eradication. The formation of NO in phagocytes is catalyzed by iNOS. However, RNS production is delayed because induction of iNOS expression requires phagocyte detection of pro-inflammatory cytokines like TNF- $\alpha$ [47]. 


\section{S. schenckii Recognition by Macrophages}

The establishment of an infectious disease is influenced by the immune status of the host, the pathogenicity of the fungus, as well as the established interactions between them. Although it is true that the mechanisms of infection, the site of infection, and the strain and burden of the pathogen, among other aspects, are relevant, a first step is the recognition of the infectious agent by the host to activate the innate immune response early, and then to link and activate a specific adaptative immune response, when applicable [52].

Macrophages represent one of the most important lines of defense against a variety of pathogens, including S. schenckii. PRRs in macrophages such as TLRs, the nucleotidebinding oligomerization domain (NOD)-like receptors (NLRs) family pyrin domain containing 3 (NLRP3), and Dectin-1 have been studied in response to the recognition of PAMPs of this fungus, like cell surface antigens (either as hyphae or as yeast) and fungal cell surface lipids [53] (Figure 1). It is important to note that the differences in the CW architecture and composition of pathogenic fungi impact host recognition by innate immune cells [54].

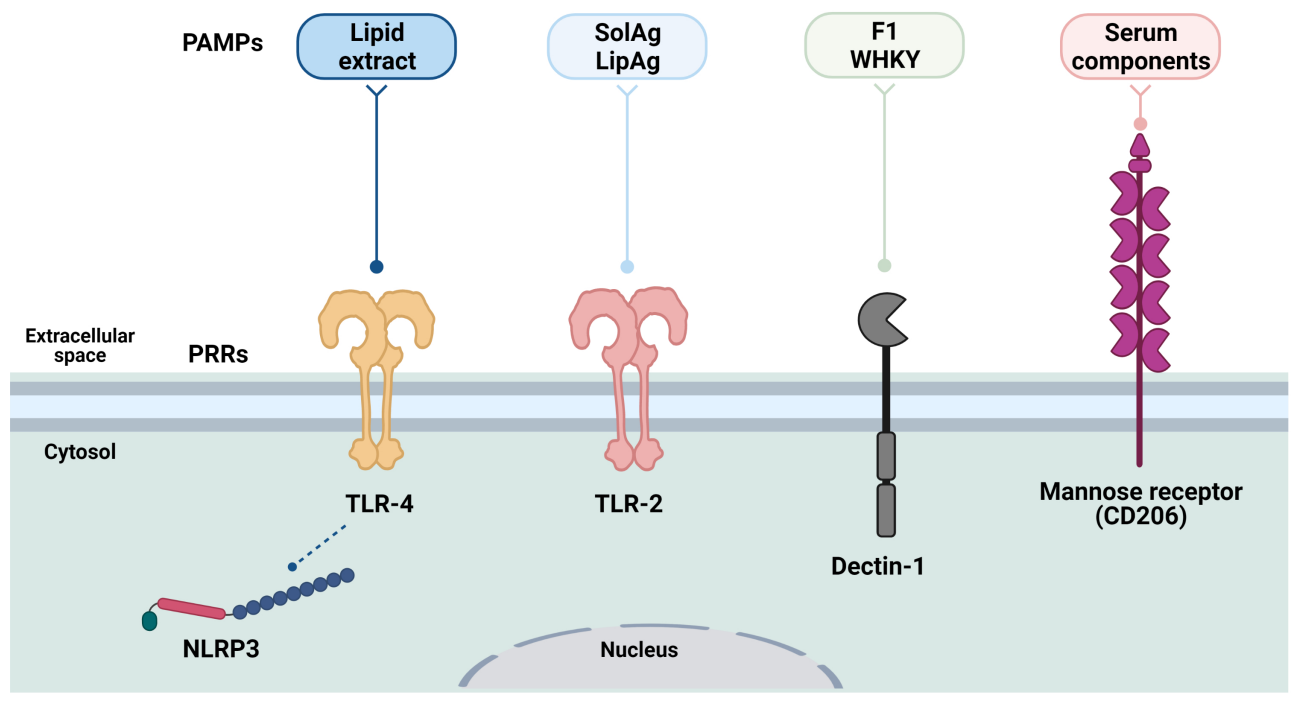

Abbreviations: PRRs= Pattern recognition receptors; PAMPs= Pathogen-associated molecular patterns; TLR= Toll-like receptors; SolAg= Surface soluble antigen; LipAg= Lipidic antigen; F1 = Alkali-insoluble fraction 1; WHKY= Whole heat-killed yeast; NLRP3= Nucleotide-binding

Figure 1. Receptors and ligands mediating S. schenckii recognition and phagocytosis by macrophages. Some PRRs like TLR-2 and -4, Dectin-1, and mannose receptor have been associated with recognition of some PAMPs as SolAg, LipAg, F1, WHKY, or some serum components associated with infection by S. schenckii. Thus far, it has only been proposed that the NLRP3 inflammasome can occur upon recognition of PAMPs by TLR-4.

TLRs are the best characterized PRR family because of the recognition of various fungal pathogens [55]. At present, more than ten TLRs are known, but only TLR-2 and TLR-4 have been involved in the immune response induced by sporotrichosis during the recognition of S. schenckii by macrophages and its inflammatory activation [56]. It is well known that TLR-2 recognizes fungal glycolipid phospholipomannan and zymosan, while TLR-4 recognizes the O-linked mannosyl residues, glucuronoxylomannan, and galactomannan [57].

The first PRR associated with S. schenckii recognition was TLR-4, and it has been involved in the secretion of pro-inflammatory and anti-inflammatory mediators. In peritoneal macrophages of mice with sporotrichosis, a correlation has been shown between the presence of TLR- 4 and the secretion of both pro-inflammatory (TNF- $\alpha$ ) and anti-inflammatory (IL-10) mediators during sporotrichosis. The nuclear translocation of the nuclear factor kappa-light-chain-enhancer of activated B cells (NF- $k \mathrm{~B}$ ) was elevated in the second week, coinciding with a significant increase in TNF- $\alpha$ during the first four weeks, which could 
suggest an inflammatory period of sporotrichosis, while higher levels of IL-10 production were observed in the final stages of the study, suggesting its possible role as an inhibitor of TNF- $\alpha$ secretion and, therefore, as an anti-inflammatory cytokine during infection. On the other hand, the secretion of NO, which increased between the 4th and 8th weeks, and the cellular apoptosis of peritoneal macrophages that was detected between the 4 th and 6th weeks in mice may be involved in the immunosuppressive state observed at this time $[58,59]$. Something worth pointing out in this work is the fact that IL- $1 \beta$, IL-6, and $\mathrm{H}_{2} \mathrm{O}_{2}$ increased their secretions during the entire ten weeks of infection and, although IL-1 $\beta$ decreased in the fourth week, it maintained higher concentrations as opposed to those in the non-inoculated control mice. In TLR-4-deficient mice, the TGF- $\beta$ secretion increases, which could indicate that the secretion of this cytokine could negatively affect the inflammatory activation of macrophages during sporotrichosis in mice [60]. In in vitro assays, it was determined that TLR-4 played a less important role as opposed to TLR-2 during the interaction of Sporothrix with human PBMCs than with murine cells [17], which suggests interspecies differences that should be taken into account when explaining the immune response in this mycosis.

The role of TLR- 2 in IL-1 $\beta$, IL-12, IL-10, and TNF- $\alpha$ secretion and phagocytosis has also been demonstrated in mice's peritoneal macrophages during a 10-week S. schenckii infection period. Remarkably, IL-12, as an important mediator for the activation of the type 1 response, together with $\mathrm{NO}$, reached their maximum concentration at week $6[53,61,62]$. High levels of IL-12 are maintained by IFN- $\gamma$ [63], which is a powerful activator of macrophages and type 1 cells that respond against fungal pathogens [64].

After TLR activation and the consequent production of pro-IL- $1 \beta$ and pro-IL- 8 mediated by NF- $\kappa \mathrm{B}$, the assembly of the multimeric complex of NLRP3 forming the inflammasome promotes the proteolytic processing of pro-caspase- 1 to active caspase- 1 , which cleaves pro-IL- $1 \beta$ and pro-IL- 8 to produce mature secreting forms of IL- $1 \beta$ and IL-18, both important mediators of inflammation $[65,66]$. Inflammasome activation represents an important mechanism of protection against $S$. schenckii infection since macrophages from $\mathrm{ASC}^{-/-}$and caspase $-1^{-/-}$null mice (both deficient in the activation of the inflammasome) have an impaired control of $S$. schenckii infection [67].

One more PRR associated with the recognition of $S$. schenckii is Dectin-1, which is a Ctype lectin-like receptor and the major fungal $\beta$-1,3-glucans receptor on macrophages [68,69]. Like TLR-2 and TLR-4, Dectin-1 could stimulate peritoneal macrophages to secrete pro(TNF- $\alpha$ and IL-1 $\beta$ ) and anti-inflammatory (IL-10) mediators, increasing either its phagocytic activity or NO release [70]; in addition, this receptor has an important role in cytokines secretion against yeast and conidia of $S$. schenckii, mainly IL-10 in human PMBCs [17].

\section{Macrophages and the Immune Responses in Sporotrichosis}

The principal components of innate immunity are the skin and mucous membranes, which contain antigen presenting-dendritic cells and other migratory phagocytic cells, expressing constitutively PRRs that recognize PAMPs and secrete soluble mediators, generating inflammation reactions and supporting the development of the adaptive immune responses. Cellular and soluble components of innate immunity respond immediately in a coordinated manner after antigen recognition [71,72]. These essential functions of innate immunity for controlling the growth of $S$. schenckii yeast cells were revealed in mice with a defective mechanism to generate ROS - a lack of the NADPH oxidase functionwhereby defective mice developed disseminated lethal sporotrichosis after subcutaneous inoculation of the fungus, in contrast to wild-type mice who controlled the infection and survived [73]. Since then, several studies have demonstrated the role of CD4 ${ }^{+} \mathrm{T}$ cells and activated macrophages during sporotrichosis infection and pathogen clearance in athymic nude [74-77] and Swiss mice [78,79]. These findings pointed to macrophages being relevant cells in the afferent and the efferent arms of the immune response against $S$. schenckii, in the context of type 1 and type 17 protective responses [80-82]. Infected and inflamed tissues release damage-associated molecular patterns (DAMPs) also recognized 
by PRRs. Macrophages participate in the structural remodeling after tissue damage as anti-inflammatory cells (M2 macrophages), in the setting of type 2 responses. In an ex vivo sporotrichosis model, after $S$. schenckii infection, using peritoneal exudate cells challenged with CW peptide-polysaccharide, macrophages M2 were the predominant cell population. These alternative activated macrophages expressed peaks of arginase-I activity as well as IL-10 and TGF- $\beta$ production during the 6 th and 8th weeks after infection [83]. The timing of macrophages participation in S. schenckii infection or in sporotrichosis should be considered in in vivo studies, particularly in order to understand the immunopathogenesis of sporotrichosis in humans. However, most of the S. schenckii-infected humans do not develop sporotrichosis, and rarely do they develop the systemic forms of the disease [84]. Murine models and in vitro studies have provided a wealth of information on the pathogenicity and virulence mechanisms of the fungus and on the cellular and molecular responses by the host's immune system. Extrapolation of these results to explain the immunopathogenesis of sporotrichosis in humans should be done cautiously. An example of the latter are the studies related to the involvement of macrophages in the immunopathology of this disease [85]. It is common to overlook the morphological and functional heterogeneity of these innate immune cells and the relevance of tissue microenvironments in which the macrophage-S. schenckii interaction naturally occurs. Temporal and functional plasticity is a distinctive feature of macrophages as they act as host cells, effector cells, immunoregulatory cells, and tissue repair cells [30]. In this respect, it is pertinent to ask whether dermal resident macrophages, peritoneal macrophages, inflammatory monocytes, and the human monocytic cell line THP-1 are equivalent for studying the infection's timing with a dimorphic fungus such as S. schenckii.

The ingestion of fungal cells of $S$. schenckii triggers the oxidative burst in murine macrophages, and their stimulation with IFN- $\gamma$ induced $\mathrm{NO}$ production and inhibition of fungal growth, indicating that $\mathrm{NO}$ is a fungicidal mediator against $S$. schenckii in vitro [86]. However, this fungicidal activity and NO production by IFN- $\gamma$ and LPSactivated macrophages were abolished after the infection of yeast cells in a murine model of systemic sporotrichosis. Moreover, mice deficient in inducible nitric oxide synthase (iNOS $^{-/-}$) and C57BL/ 6 wild-type (WT) mice treated with N-omega-nitro-arginine, an iNOS inhibitor, presented fungal resistance, controlling fungal load in tissues, and restoring T-cell activity, as well as producing high amounts of IFN- $\gamma$. These findings suggest that the activation of the NO system in vivo contributes to the immunosuppression and cytokine balance during the early phases of infection with S. schenckii [87]. In human sporotrichosis, activation of the NO system or the iNOS expression has been correlated with the intensity of the inflammatory infiltrate and the number of neutrophils in chronic skin lesions from the lymphocutaneous form, compared to the fixed form, observing a greater infiltrate in the lymphocutaneous form, a more common clinical presentation of sporotrichosis [88]. In addition, the lymphocutaneous form presented a higher percentage of $\mathrm{CD}^{+} \mathrm{T}$ cells, and $\mathrm{CD} 22^{+} \mathrm{B}$ cells, than the fixed form, but no differences in macrophages, $\mathrm{CD} 3^{+}$, and $\mathrm{CD}^{+}$cells were observed in the two disease forms. Despite the higher expression of iNOS and the lack of differences in macrophages, a great fungal burden was found in skin lesions from the lymphocutaneous form, compared to the fixed form. Thus, this ineffective fungus control in the lymphocutaneous form could be related to a higher virulence of some $S$. schenckii strains as demonstrated in animal models $[89,90]$. Recently, it has been proposed that the immunopathological and clinical characteristics of the lymphocutaneous form of sporotrichosis may indicate either an initial uncontrolled or an ineffective inflammatory process that characterizes an unbalanced immune response [91]. Fixed lesions commonly present more focal inflammatory infiltrates, surrounded by fibrous tissue that could impair dissemination of the fungus, facilitating its control. Probably, alternative activated macrophages with arginase-I activity as well as with IL-10 and TGF- $\beta$ attenuate the inflammatory response and activate fibroblasts for collagen synthesis via TGF- $\beta$ [92]. On the other hand, the presence of intense and diffuse, non-fibrotic inflammatory infiltrate, with intense necrosis and suppurative reactions, could facilitate lymphatic dissemination 
of the fungus in the lymphocutaneous form of human sporotrichosis [93]. Since both clinical forms showed no differences in the percentage of macrophages, but rather in the percentage of neutrophils, which was higher in the lymphocutaneous form [88], it may be suggested that, in the fixed form, the less severe form of sporotrichosis, an efficient collaboration between macrophages and neutrophils occurs to limit and repair tissue damage, decreasing the fungal burden and preventing the spread of the infection. The immune response mechanism involved in the macrophage-S. schenckii interaction is summarized in (Figure 2).

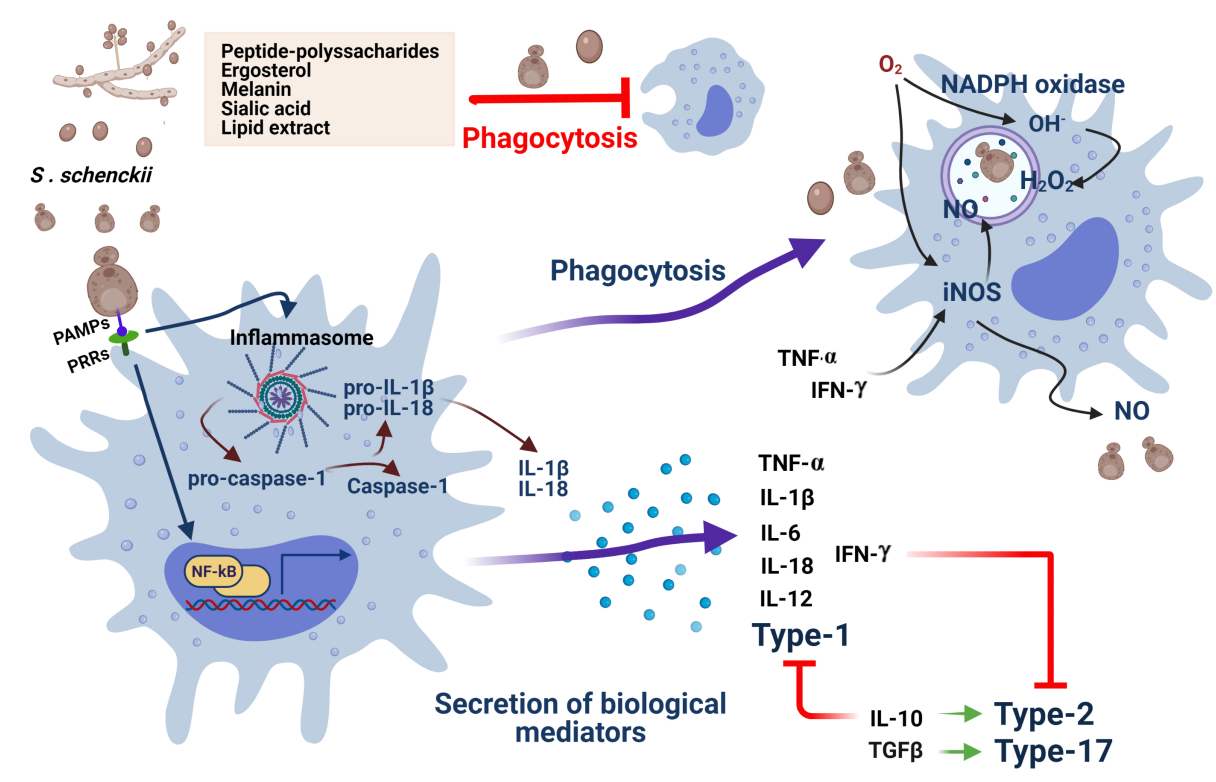

Abbreviations: PRRs $=$ Pattern recognition receptors; PAMPs = Pathogen-associated molecular patterns; $\mathbf{N F}-\mathbf{k B}=$ Nuclear factor kappa-light-chain-enhancer of activated $B$ cells; $\mathbf{N A D P H}=$ Nicotinamide adenine dinucleotide phosphate; $\mathbf{H}_{2} \mathrm{O}_{2}=$ Hydrogen peroxide; $\mathrm{OH}^{-}$ Hidroxyl radical; iNOS= Inducible nitric oxide synthase; NO= Nitric oxide; IL= Interleukine; TNF- $a=$ Tumor necrosis factor-alfa; IFN- $\mathbf{y}=$

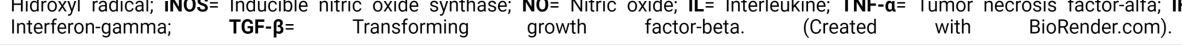

Figure 2. Recognition of S. schenckii and macrophages activation. After recognition of cellular PAMPs of $S$. schenckii by macrophage PRRs, phagocytosis and secretion of biological mediators can be activated. Phagocytosis and respiratory burst, with the participation of NADPH oxidase and the consequent formation of ROS, such as $\mathrm{H}_{2} \mathrm{O}_{2}$, will focus on fungal clearance within the phagosome. On the other hand, the formation of RNS, such as NO, with the participation of iNOS, should have the same function as ROS; however, $\mathrm{NO}$ has been associated with a state of immunosuppression after several weeks of infection. It is also important to note that cellular components of $S$. schenckii can prevent its phagocytosis by macrophages. In addition to phagocytosis, secretion of biological mediators associated with nuclear translocation of NF- $\kappa \mathrm{B}$ can occur. This translocation, with the participation of caspase-1, can promote the assembly of the NLRP3 inflammasome, inducing cytokine secretion. In any case, the secretion of biological mediators can promote either inflammatory (TNF- $\alpha$, IL-1 $\beta$, IL-6, IL-12, IL-18, IFN- $\gamma$ ) (cellular response type 1) or anti-inflammatory (IL10, TGF- $\beta$ ) (cellular response type 2 and 17) processes. Interestingly, TNF- $\alpha$ and IFN- $\gamma$ ) may be related with the activation of iNOS and the formation of NO. Furthermore, IFN- $\gamma$ can also block type- 2 and 17 responses, while IL-10 can block type 1 response.

\section{Macrophage-S. schenckii Interaction: Some New Aspects}

Optimal binding and phagocytosis of $S$. schenckii conidia by the human monocytic cell line THP-1 require opsonization with normal human serum components, which are recognized by MR. Opsonized conidia uptake stimulates the production of ROS, resulting in the killing of conidia. Interestingly, THP-1 cells appeared to use complement receptors to phagocytize yeast cells, followed by ROS production. Release of TNF- $\alpha$ was not stimulated by opsonized or non-opsonized conidia, whereas opsonized and non-opsonized yeast cells did release it. The different pro-inflammatory response induced by S. schenckii morphotypes could be related to the progression of the inflammation after the natural infection with this 
fungus [94]. Some of these results were confirmed recently, using human monocyte-derived macrophages incubated with non-opsonized or opsonized conidia with $10 \%$ normal human serum or serum proteins absorbed into conidia as albumin, transferrin, serum amyloid P component (SAP) or $\alpha 1$-antitrypsin (AAT) identified by tandem mass spectrometry. In addition, it was demonstrated that conidia phagocytosis depended on the concentration of SAP or AAT, and it is worth pointing out that the competition assay with D-mannose did not affect macrophage phagocytosis, which suggests that the MR is not involved. Transferrin or albumin did not have any effect on conidia uptake. This work opens up new routes in investigating the role of other innate immunity proteins in fungal diseases and in systemic or deep sporotrichosis [95]. The SAP is a hepatocyte secreted circulating lectin with specificity for the cyclic 4,6-pyruvate acetal of galactose [96], which can bind to the surface of some bacteria and fungi, helping the complement-mediated immunity [97]; in addition, this lectin can be identified as a friend or foe of the host in bacterial and fungal infections [98-100]. Macrophage phagocytosis and the concomitant reduction of inflammatory cytokines have been observed after SAP binds to functional and pathogenic amyloid on the surface of fungi such as Candida albicans [101-103], Aspergillus, Mucorales, and Coccidioides[100] that produce deep mycoses.

On the other hand, AAT, one of the most abundant serine protease inhibitors, has anti-inflammatory activity against key innate immune response cells such as neutrophils, macrophages, monocytes, and mast cells [104], and it could be relevant to explore them in natural and experimental $S$. schenckii infections and in the most common clinical forms of sporotrichosis [88]. The rapid recruitment of neutrophils to injury or infection sites is mediated by IL-8, also known as CXCL8 (a chemokine produced by macrophages and endothelial cells). Such recruitment is a hallmark of the inflammatory response and is required for the host's effective defense against pathogenic stimuli [105]. However, neutrophils can also lead to chronic tissue destruction, facilitating, as it has been mentioned previously, the lymphatic dissemination of S. schenckii in the lymphocutaneous form of human sporotrichosis and altering the antifungal cooperation with macrophages [88]. The ATT, as a regulatory enzyme that inhibits neutrophil proteases' activity, such as elastase [106], would limit host-tissue injury, attenuating the inflammatory response and avoiding the fungus dissemination, as in other infections.

Hepatocytes, the major parenchymal cells in the liver, produce SAP and ATT, and hundreds of other acute-phase proteins, exhibiting a wide variety of functions including the activation of innate immunity [107]. It is well known that customary consumption of alcohol can cause chronic liver damage and hepatic dysfunction. It is likely to assume that the altered secretion of SAP and ATT, along with other immunosuppressive mechanisms present in alcoholic patients, contributes to the development of disseminated cutaneous and pulmonary sporotrichosis [2,108-110]. However, liver resident macrophages could be also implicated.

Hepatic macrophages, also known as Kupffer cells, are F4/80 ${ }^{+}$phagocytes that downregulate CR3 but express CRIg (a tissue-specific complement receptor) and CLEC4F (a liver-specific C-type lectin for alpha-galactosyl ceramide), which defines their innate recognition function and adhesion [111]. Kupffer cells also express the MR, involved in clearance of mannosylated glycoconjugated [112], and the class A scavenger receptor (SR-A), a multiligand and multifunctional receptor of polyanionic ligands [113]. The interactions between the Kupffer cells and fungal pathogens are scarcely understood, and S. schenckii is not the exception. The disseminated sporotrichosis models in mice with liver involvement have set aside the study of the Kupffer cells, the body's largest population of resident macrophages. As embryonic-derived macrophages, Kupffer cells induce liver metabolic responses such as biosynthesis of acute phase plasma proteins to combat acute and chronic infections [114]. It is likely that cytokines mediate interactions between hepatocytes and Kupffer cells during fungal infections. Experiments with a primary culture of murine TLR-4-deficient Kupffer cells from C57BL/ScCr mice suggest that the cytokine response (TNF- $\alpha$, chemokines keratinocyte-derived chemokine (KC) and MIP-2) to the fungal component of $A$. fumigatus 
and C. albicans hyphae and conidia is not mediated by TLR-4 but by tyrosine kinases [115]. This contrasts with the results obtained using peritoneal macrophages from TLR-4-deficient $(\mathrm{C} 3 \mathrm{H} / \mathrm{HeJ})$ and control mice $(\mathrm{C} 3 \mathrm{H} / \mathrm{HePas})$ infected with $S$. schenckii yeast cells, where significantly greater amounts of pro-inflammatory mediators, such as NO and TNF- $\alpha$ (early-stage post-infection), and anti-inflammatory cytokines, such as IL-10 (late-stage postinfection), were produced by thioglycollate-elicited peritoneal macrophages from infected $\mathrm{C} 3 \mathrm{H} / \mathrm{HePas}$ mice [58]. In this work, the authors suggest that other receptors like TLR-2 and Dectin-1 may also contribute to the immune response during $S$. schenckii infection, but they assign TLR-4 an important role in governing the functions of macrophages in fungal infection. However, the origin and functional status of resident macrophages used in similar studies must also be considered.

Much of the knowledge about the macrophage-S. schenckii interaction derives from in vitro and in vivo studies using murine peritoneal macrophages which, as Kupffer cells, are $\mathrm{F} 4 / 80^{+}$. However, the origin (ontogeny), differentiation, phenotypic differences, and the organ-specific trophic functions of macrophages are heterogeneous variables that could mainly limit an interspecies extrapolation of conclusions, and, moreover, in terms of a human perspective [26]. Furthermore, the peritoneal cavity is not the most frequent site of entry for S. schenckii. This serosa contains an independent reserve subpopulation of large and mature resident macrophages that expresses the transcription factor GATA-6. They migrate rapidly to regional lymph nodes after stimulation and are recruited after sterile injury to the liver, acquiring an alternative activation phenotype (M2) characterized by anti-inflammatory and tissue damage repairing actions $[43,116,117]$. Thus, what kind of macrophage peritoneal subpopulation is suitable to study the infection by the Sporothrix species?

Phagocytic capacity is variable among resident macrophages from different organs and is mediated by distinct repertoires of receptors, opsonins, and transcription factors from each tissue, indicating that heterogeneity is established by local tissue-derived factors [118]. The liver and the peritoneal cavity exemplify this fact, increasing the complexity by containing several macrophages of distinct origins, whose activation and function most likely reflects a spectrum of changes, rather than the simplistic M1/M2 binary division [32]. This concept can be extended to the skin, the host's natural way by which more frequently Sporothrix species enter.

\section{A New Population of $M R^{h i} / A r g-1$ and iNOS Negative Dermal Resident Macrophages in Mice}

The ontogeny and tissue-derived signals shape the functional specialization and plasticity of macrophages $[119,120]$. The origin of macrophages plays an important role in their functional adaptation in accordance with the limited reprogramming of peritoneum-resident macrophages, compared to recruited monocyte-derived macrophages in an infection-driven inflammatory model [121].

Little is known regarding the plasticity of dermal resident macrophages and their relative contributions to antimicrobial immunity or to pathology in cutaneous infection. Under steady-state conditions, mice's dermis contains a population of M2-like resident macrophages of embryonic origin, so they are not replaced by recruited blood precursors (monocytes or other bone-marrow derived cells). During infection by the highly virulent Leishmania major Seidman, these dermal macrophages promote an MR-dependent fashion and non healing cutaneous disease, similar to inflammatory response accompanied with $\mathrm{CD}^{+}$cell in lymphocutaneous sporotrichosis [91]. These MR high $\left(\mathrm{MR}^{h i}\right)$ (or CD206 ${ }^{\text {high }}$ ) dermal resident macrophages, including $\mathrm{CD}^{-} 6^{-}, \mathrm{CD}^{209}{ }^{-}$, and $\mathrm{CD} 301$ (macrophage galactose-type calcium-type lectin, MGL or CLEC10A)-positive, are locally maintained by eosinophil-derived IL-4 and IL-10 and retain M2 functionality despite the high levels of IFN- $\gamma$ and TNF- $\alpha$ produced by activated monocyte-derived subsets within the same tissue environment [122,123]. Notably, these embryonic M2-like dermal resident macrophages were negative for arginase-1 (Arg-1) as well as iNOS, and their gene expression profiles are likely to be distinct from other M2 populations promoted by a specific 
set of cytokines and microbial stimuli in vivo or in vitro [124]. The CD206 ${ }^{\text {high }}$ M2-like dermal macrophages share some similarities with pleural cavity resident macrophages, whose renewal after a helminth infection in the pleural cavity (polarized type 2 response) resulted in IL-4-dependent proliferative expansion with minimal recruitment of adult bone marrow-derived cells [125]. Interestingly, self-renewal and functional attributes of M2-like dermal macrophage cells occurred within a strong proinflammatory environment of the $L$. major-loaded dermis.

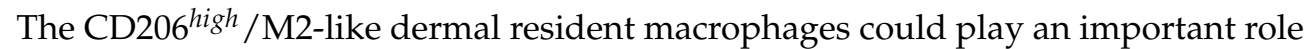
in all evolution stages of experimental skin infection with $S$. schenckii because the MR has already been involved in the binding and phagocytosis of opsonized conidia [86], without the release of TNF- $\alpha$, while conversely releasing TNF- $\alpha$ and producing ROS induced by phagocytosis of opsonized and non-opsonized yeast. Dermal macrophages may have lost their responsiveness to TNF, which would normally function to antagonize their alternative activation [126]. This suggests that the dermis would have a proclivity to mount M2 macrophage-mediated responses in murine models of infection from the beginning of the interaction with some pathogens. This early response would be added to the alternative activation of M2 macrophages recruited and derived from monocytes after several weeks of infection development. The latter agrees with the results obtained after intraperitoneal inoculation of mice with yeast cells of $S$. schenckii. A predominance of M1 macrophages was demonstrated during the 2nd and 4th weeks post-infection, but, during the 6th and 8th weeks after infection, a predominance of CD206 ${ }^{+} \mathrm{M} 2$ macrophages, in response to type 2 cytokines, was identified [83]. The population of $\mathrm{MR}^{h i} \mathrm{M} 2$ dermal macrophages was identified by combining MR and Ly6C staining on CD11b ${ }^{+}$lin $^{-}$cells. Their functional specialization for apoptotic cell capture and the local type 2 cytokines contribute to establishing and maintaining their M2 activation program [91].

\section{The Macrophage-S. schenckii Interaction: Virulence/Pathogenicity or Survival Factor?}

Macrophages play a key role in the host's response against pathogens. The expression of cell surface receptors activated by molecules derived from both the host and pathogens are relevant to the macrophage's innate immune response [18]. However, these phagocytic cells act either as hosts/niches for intracellular pathogens evading the immune responses or as antigen-presenting cells and promoters of an adaptive immune response [20]. Tachibana et al. [77] have demonstrated the role of macrophages against $S$. schenckii. These authors used previously subcutaneously immunized mice to obtain lymph node cells which were adoptively transferred to naive congenitally athymic nude mice. The ability to transfer protection against a $S$. schenckii infection was significantly reduced when lymph node cells were depleted of $\mathrm{CD} 4^{+} \mathrm{T}$ cells and abolished when macrophages of mice were blocked with carrageenan. An in vitro study, using either immune lymph node cells alone or macrophages alone, failed to kill the fungus. However, inhibition of fungal growth was observed when both immune lymph node cells and macrophages were combined [77].

Macrophage receptors play an important role in the development of an effective innate immune response against pathogens since they mediate phagocytosis, signaling cascades, intracellular traffic, inflammatory response, and antigen presentation [48]. The receptors involved during S. schenckii's antigen recognition as well as the activated signaling cascades have been previously reviewed [19]. Although Martínez-Alvarez et al. [17] observed variations in the chitin content of the CW of conidia, yeasts, and germ tubes of S. schenckii, the proportion of carbohydrates (rhamnose and glucose) is similar in all of them. This could explain why they are all capable of activating the secretion of pro-inflammatory cytokines from PBMCs. On the other hand, Lopes-Bezerra et al. [15] showed that 4-day-old $S$. schenckii yeasts were more easily engulfed than 10-day-old ones by human monocytes. Additionally, they observed that the fungus shed layers of the $\mathrm{CW}$ during its growth, which can cause antigenemia or inflammation at a distance from the site of the pathogen stem cell. In addition, if shed layers of CW contain PAMPs, these can function as decoys for PRRs 
in macrophages and evade phagocytosis, which could influence the infection process and disease development. Phagocytosis of serum opsonized S. schenckii conidia by the human monocytic cell line THP-1 requires the recognition by MR, and it induces the production of ROS, resulting in the killing of conidia. This monocytic cell line produces ROS after phagocytose yeast cells using complement receptors. Release of TNF- $\alpha$ was not stimulated by opsonized or non-opsonized conidia, whereas opsonized and non-opsonized yeast cells did release it. These findings highlight the relevance of $S$. schenckii morphotypes to induce different pro-inflammatory responses that could be related to the progression of the natural infection with this fungus [94], and they suggest that dimorphism is a pathogenicity factor more than a survival factor for S. schenckii [127-131]. However, neither S. schenckii morphology nor macrophages receptors are the only features that influence the macrophage- $S$. schenckii interaction since the composition of the surface of the fungus plays a lead role. In this regard, Sgarbi et al. [132] studied the presence of ergosterol, a compound on the surface of $S$. schenckii capable of sequestering ROS and avoiding the damage produced by effector cells from the immune response such as macrophages. Remarkably, this study demonstrated that an enzymatic extract obtained from the same fungus reverted ergosterol peroxide to ergosterol, regenerating ergosterol and increasing the resistance of the fungus to ROS, which enhances the virulence of the fungus. Ergosterol has been also associated with antifungal resistance. Brilhante et al. [133] showed how diminishing the concentration of ergosterol through terpinene-4-ol, a monoterpene that exhibits antifungal activities increases the susceptibility of $S$. schenckii to itraconazole, amphotericin B, and terbinafine, the first choice antifungals used for sporotrichosis treatment. Furthermore, Borba et al. [134], using an inhibitor for $\Delta(24)$-esterol methyltransferase, an enzyme that participates in ergosterol biosynthesis, increased the susceptibility of $S$. schenckii to itraconazole, suggesting a new role of ergosterol in the virulence of the fungus. According to the latter works, it must be noted that a diminishment in ergosterol levels interferes with the structure of S. schenckii's CW, a structure that mediates its interaction with immune response cells such as macrophages.

Antifungal resistance of $S$. schenckii to macrophages has also been associated with melanin production [135]. Almeida et al. [136], using inhibitors for eumelanin and pyomelanin production during $S$. schenckii growth in the presence of terbinafine, a recommended therapeutic alternative for sporotrichosis treatment, demonstrated that melanin content has the potential to protect $S$. schenckii and S. brasiliensis strains from antifungal effects induced by terbinafine since the presence of melanin increased the minimal inhibitory and fungicidal concentrations. However, the potential protector role of melanin on different species of the Sporothrix complex such as S. globosa, S. luriei, and S. pallida has been and remains poorly studied. In vitro studies have also shown that $S$. schenckii conidia without melanin production are highly phagocyted, compared with melanin pigmented conidia, which indicates that melanin contributes to fungal survival within the host, increasing its virulence [137]. Fungal cells' melanization can also affect the pathogenesis of the fungus since pigmented isolates of $S$. schenckii have demonstrated a higher ability to invade tissues, compared with albino strains [138].

Yeast morphotype of $S$. schenckii, contrary to the conidial phase, possesses two concanavalin A (Con A) reactive layers on the external surface of the CW. These layers can break off from the cell during its interaction with immune response cells. This released material from S. schenckii's CW contains peptidorhamnomannan and galactomannan antigens, as well as anionic surface groups detectable through reactions with ferritin. These polysaccharide antigens purified from the $C W$ of $S$. schenckii inhibited in vitro yeast cell phagocytosis by murine peritoneal macrophages [139]. Conversely, the treatment of yeast cells of $S$. schenckii with neuraminidase diminished the presence of sialic acid and modified the structure of both surface layers, increasing the phagocytosis index of the fungus [140].

Galactomannans and rhamnomannan polysaccharides have been suggested as regulators or inhibitors of the immune response since macrophages incubated with these compounds increase the production of L-arginase, TGF- $\beta$, and IL-10, molecules with anti- 
inflammatory activities. In fact, peptide-polysaccharide antigens expressed at the CW of yeast cells of $S$. schenckii could be dual activators of macrophages, capable of inducing the classical pathway (M1) and a type 1 response, as well as of eliciting the alternative pathway (M2) and a type 2 response, according to the fungal infection course [83], and they can also diminish cellular response in murine sporotrichosis models [79]. The inhibition of the in vitro phagocytosis, along with the induction of a high release of TNF- $\alpha$ and NO, has also been attributed to a lipid component from the CW of S. schenckii [141]. Moreover, soluble and lipidic antigens from the fungal cell surface can activate macrophages by targeting their TLR-2, increasing the secretion of TNF- $\alpha$, IL- $1 \beta$, and IL-10 [53], whereas the same lipidic antigen increases the production of TGF- $\beta$ in macrophages isolated from TLR- 4 deficient mice [58]. Additionally, it has been demonstrated that murine splenic macrophages increase the production of IFN- $\gamma$ and $\mathrm{NO}$ after being stimulated with an exoantigen of S. schenckii; however, peritoneal macrophages could be induced to express early classical activation, during the first few weeks, and then an alternative activation in the late stages of a systemic infection of Swiss mice with S. schenckii yeast cells [63,82]. Lipidic antigen activates caspase-1 [142], which plays a fundamental role in innate immunity and in several important inflammatory diseases. This protease activates the pro-inflammatory cytokines proIL-1 $\beta$ and pro-IL-18, which could induce pyroptosis, a caspase-1-dependent type of programmed cell death. In addition, there is evidence that caspase-1 supports cell survival by activation of NF- $\kappa \mathrm{B}$, induction of membrane repair, and regulation of unconventional secretion of certain proteins [65]. Some of these partially opposing effects of caspase-1 activation by a lipidic antigen from the $\mathrm{CW}$ of $S$. schenckii have not been studied neither in human sporotrichosis nor in murine models of this fungal disease. Understanding the virulence/pathogenicity of $S$. schenckii should allow for the consideration that different subsets of macrophages, from different microenvironments and mammalian species, have a different potentiality to recognize, phagocytose, and eliminate both conidia and yeast cells of S. schenckii; in addition, it should allow for bearing in mind that this fungus is able to modulate the macrophage's activation, inhibiting or increasing the production of ROS and RNS that does or does not enhance the overall defense immune responses of the host. In the natural and in vivo experimental infections, other innate immune response cells such as DC, mast cells, and neutrophils participate with other defense mechanisms to give a more comprehensive and integrated response by the host to control the infection by $S$. schenckii. Finally, conidia, mycelia, and the yeast forms of S. schenckii secrete active enzymes as acid phosphatase that participate as a virulence factor during the macrophage-fungus interaction $[143,144]$.

\section{Conclusions}

In the immune system, human cells participate against microbial pathogens. Macrophages play an important role in both the activation of the innate immune system and the elimination of the pathogenic forms of the genus Sporothrix. Macrophage receptors play a key role in activating an effective immune response against the fungus, as they mediate phagocytosis, signaling cascades, intracellular trafficking, inflammatory responses, and antigen presentation. Macrophages can be activated by factors derived from the host and the pathogen. Macrophage PRRs such as TLRs, NLRs, MR, and Dectin-1 have been studied in response to recognition of PAMPs in S. schenckii. This fungus has different pathogenicity/virulence factors, such as ergosterol, melanin, polysaccharide peptides, and lipid components, some of them located on the fungal cell surface, which are involved in macrophage evasion mechanisms (Figure 2). Furthermore, before extrapolating from in vitro and in vivo studies, it is convenient to consider the morphological and functional heterogeneity of these phagocytic cells and the tissue microenvironments in which the macrophage-S. schenckii interaction occurs, to explain the immunopathogenesis of sporotrichosis in humans. Likewise, it is necessary to know even more about the immune response induced during the mycelial morphotype infection, which represents the natural infection process. 
Author Contributions: Conceptualization, E.R.-B. and Y.R.-L.; writing-original draft preparation, E.R.-B., A.P.-T., Y.R.-L., D.C.-G., C.A.A.-F., J.V.-J. and C.T.; writing-review and editing, E.R.-B., A.P.-T., Y.R.-L. and D.C.-G.; supervision, E.R.-B. and Y.R.-L. All authors have read and agreed to the published version of the manuscript.

Funding: This research received no external funding.

Institutional Review Board Statement: Not applicable.

Informed Consent Statement: Not applicable.

Data Availability Statement: Not applicable.

Acknowledgments: The authors acknowledge Rocío Reyes-Montes for the revision and suggestions made on this work and Jorge E. Macías-Díaz for the suggestions made to the manuscript format.

Conflicts of Interest: The authors declare no conflict of interest.

\section{References}

1. Chakrabarti, A.; Bonifaz, A.; Gutierrez-Galhardo, M.C.; Mochizuki, T.; Li, S. Global epidemiology of sporotrichosis. Med. Mycol. 2015, 53, 3-14. [CrossRef] [PubMed]

2. Queiroz-Telles, F.; Buccheri, R.; Benard, G. Sporotrichosis in immunocompromised hosts. J. Fungi 2019, 5, 8. [CrossRef]

3. Toriello, C.; Brunner-Mendoza, C.; Ruiz-Baca, E.; Duarte-Escalante, E.; Pérez-Mejía, A.; del Rocío Reyes-Montes, M. Sporotrichosis in Mexico. Braz. J. Microbiol. 2020, 52, 49-62. [CrossRef] [PubMed]

4. Orofino-Costa, R.; de Macedo, P.M.; Rodrigues, A.M.; Bernardes-Engemann, A.R. Sporotrichosis: An update on epidemiology, etiopathogenesis, laboratory and clinical therapeutics. An. Bras. Dermatol. 2017, 92, 606-620. [CrossRef] [PubMed]

5. Rossow, J.A.; Queiroz-Telles, F.; Caceres, D.H.; Beer, K.D.; Jackson, B.R.; Pereira, J.G.; Ferreira Gremião, I.D.; Pereira, S.A. A one health approach to combatting Sporothrix brasiliensis: Narrative review of an emerging zoonotic fungal pathogen in South America. J. Fungi 2020, 6, 247. [CrossRef]

6. Barros, M.B.D.L.; de Almeida Paes, R.; Schubach, A.O. Sporothrix schenkii and Sporotrichosis. Clin. Microbiol. Rev. 2011, 24, 633-654. [CrossRef]

7. Bonifaz, A.; Tirado-Sánchez, A. Cutaneous disseminated and extracutaneous sporotrichosis: Current status of a complex disease. J. Fungi 2017, 3, 6. [CrossRef]

8. Mahajan, V.K. Sporotrichosis: An overview and therapeutic options. Dermatol. Res. Pract. 2014, 2014, e272376. [CrossRef] [PubMed]

9. Chai, L.Y.A.; Netea, M.G.; Vonk, A.G.; Kullberg, B.J. Fungal strategies for overcoming host innate immune response. Med. Mycol. 2009, 47, 227-236. [CrossRef]

10. Aderem, A.; Underhill, D.M. Mechanisms of phagocytosis in macrophages. Annu. Rev. Immunol. 1999, 17, 593-623. [CrossRef]

11. Lee, W.L.; Harrison, R.E.; Grinstein, S. Phagocytosis by neutrophils. Microbes Infect. 2003, 5, 1299-1306. doi:10.1016/j.micinf. 2003.09.014. [CrossRef] [PubMed]

12. Jain, N.; Moeller, J.; Vogel, V. Mechanobiology of macrophages: How physical factors coregulate macrophage plasticity and phagocytosis. Annu. Rev. Biomed. Eng. 2019, 21, 267-297. [CrossRef]

13. Hernández-Chávez, M.J.; Pérez-García, L.A.; Niño-Vega, G.A.; Mora-Montes, H.M. Fungal strategies to evade the host immune recognition. J. Fungi 2017, 3, 51. [CrossRef]

14. Alba-Fierro, C.A.; Pérez-Torres, A.; López-Romero, E.; Cuéllar-Cruz, M.; Ruiz-Baca, E. Cell wall proteins of Sporothrix schenckii as immunoprotective agents. Rev. Iberoam. Micol. 2014, 31, 86-89. [CrossRef]

15. Lopes-Bezerra, L.M.; Walker, L.A.; Niño-Vega, G.; Mora-Montes, H.M.; Neves, G.W.P.; Villalobos-Duno, H.; Barreto, L.; Garcia, K.; Franco, B.; Martínez-Álvarez, J.A.; et al. Cell walls of the dimorphic fungal pathogens Sporothrix schenckii and Sporothrix brasiliensis exhibit bilaminate structures and sloughing of extensive and intact layers. PLoS Neglected Trop. Dis. 2018, 12, e0006169. [CrossRef] [PubMed]

16. Huang, L.; Zhang, J.; Du, W.; Liang, Z.; Li, M.; Wu, R.; Chen, S.; Hu, X.; Huang, H. Chitin-rich heteroglycan from Sporothrix schenckii sensu stricto potentiates fungal clearance in a mouse model of sporotrichosis and promotes macrophages phagocytosis. BMC Microbiol. 2021, 21, 190. [CrossRef] [PubMed]

17. Martínez-Álvarez, J.A.; Pérez-García, L.A.; Mellado-Mojica, E.; López, M.G.; Martínez-Duncker, I.; Lópes-Bezerra, L.M.; MoraMontes, H.M. Sporothrix schenckii sensu stricto and Sporothrix brasiliensis are differentially recognized by human peripheral blood mononuclear cells. Front. Microbiol. 2017, 8. [CrossRef]

18. Soudi, S.; Zavaran-Hosseini, A.; Muhammad Hassan, Z.; Soleimani, M.; Jamshidi Adegani, F.; Hashemi, S.M. Comparative Study of The Effect of LPS on The Function of BALB/c and C57BL/6 Peritoneal Macrophages. Cell J. (Yakhteh) 2013, 15, 45-54.

19. Alba-Fierro, C.A.; Pérez-Torres, A.; Toriello, C.; Romo-Lozano, Y.; López-Romero, E.; Ruiz-Baca, E. Molecular components of the Sporothrix schenckii Complex that induce immune response. Curr. Microbiol. 2016, 73, 292-300. [CrossRef] [PubMed]

20. Rieger, A.M.; Hall, B.E.; Barreda, D.R. Macrophage activation differentially modulates particle binding, phagocytosis and downstream antimicrobial mechanisms. Dev. Comp. Immunol. 2010, 34, 1144-1159. [CrossRef] [PubMed] 
21. Gordon, S.; Plüddemann, A.; Estrada, F.M. Macrophage heterogeneity in tissues: Phenotypic diversity and functions. Immunol. Rev. 2014, 262, 36-55. [CrossRef]

22. Gordon, S.; Plüddemann, A. Macrophage clearance of apoptotic cells: A critical assessment. Front. Immunol. 2018, 9. [CrossRef] [PubMed]

23. Birbrair, A.; Frenette, P.S. Niche heterogeneity in the bone marrow. Ann. N. Y. Acad. Sci. 2016, 1370, 82-96. [CrossRef] [PubMed]

24. Dzierzak, E.; de Pater, E. Chapter One-Regulation of blood stem cell development. In Current Topics in Developmental Biology; Bresnick, E.H., Ed.; Academic Press: Cambridge, MA, USA, 2016; Volume 118, pp. 1-20. [CrossRef]

25. Nagasawa, T.; Omatsu, Y.; Sugiyama, T. Control of hematopoietic stem cells by the bone marrow stromal niche: The role of reticular cells. Trends Immunol. 2011, 32, 315-320. [CrossRef]

26. Hoeffel, G.; Ginhoux, F. Ontogeny of tissue-resident macrophages. Front. Immunol. 2015, 6. [CrossRef] [PubMed]

27. Geissmann, F.; Jung, S.; Littman, D.R. Blood monocytes consist of two principal subsets with distinct migratory properties. Immunity 2003, 19, 71-82. [CrossRef]

28. Ginhoux, F.; Guilliams, M. Tissue-resident macrophage ontogeny and homeostasis. Immunity 2016, 44, 439-449. [CrossRef] [PubMed]

29. Hashimoto, D.; Chow, A.; Noizat, C.; Teo, P.; Beasley, M.; Leboeuf, M.; Becker, C.; See, P.; Price, J.; Lucas, D.; et al. Tissue-resident macrophages self-maintain locally throughout adult life with minimal contribution from circulating monocytes. Immunity 2013, 38, 792-804. [CrossRef]

30. Gordon, S.; Plüddemann, A. Tissue macrophages: Heterogeneity and functions. BMC Biol. 2017, 15, 53. [CrossRef] [PubMed]

31. Gordon, S. Phagocytosis: An immunobiologic process. Immunity 2016, 44, 463-475. [CrossRef]

32. Martinez, F.O.; Gordon, S. The M1 and M2 paradigm of macrophage activation: Time for reassessment. F1000prime Rep. 2014, 6. [CrossRef]

33. Bonnardel, J.; Guilliams, M. Developmental control of macrophage function. Curr. Opin. Immunol. 2018, 50, 64-74. [CrossRef]

34. Sheng, J.; Ruedl, C.; Karjalainen, K. Most tissue-resident macrophages except microglia are derived from fetal hematopoietic stem cells. Immunity 2015, 43, 382-393. [CrossRef]

35. Ziegler-Heitbrock, L.; Ancuta, P.; Crowe, S.; Dalod, M.; Grau, V.; Hart, D.N.; Leenen, P.J.M.; Liu, Y.J.; MacPherson, G.; Randolph, G.J.; et al. Nomenclature of monocytes and dendritic cells in blood. Blood 2010, 116, e74-e80. [CrossRef]

36. Ingersoll, M.A.; Spanbroek, R.; Lottaz, C.; Gautier, E.L.; Frankenberger, M.; Hoffmann, R.; Lang, R.; Haniffa, M.; Collin, M.; Tacke, F.; et al. Comparison of gene expression profiles between human and mouse monocyte subsets. Blood 2010, 115, e10-e19. [CrossRef]

37. Yang, J.; Zhang, L.; Yu, C.; Yang, X.F.; Wang, H. Monocyte and macrophage differentiation: Circulation inflammatory monocyte as biomarker for inflammatory diseases. Biomark. Res. 2014, 2, 1. [CrossRef] [PubMed]

38. Mosser, D.M.; Edwards, J.P. Exploring the full spectrum of macrophage activation. Nat. Rev. Immunol. 2008, 8, 958-969. [CrossRef] [PubMed]

39. Chow, A.; Brown, B.D.; Merad, M. Studying the mononuclear phagocyte system in the molecular age. Nat. Rev. Immunol. 2011, 11, 788-798. [CrossRef]

40. Reese, T.A.; Liang, H.E.; Tager, A.M.; Luster, A.D.; Van Rooijen, N.; Voehringer, D.; Locksley, R.M. Chitin induces accumulation in tissue of innate immune cells associated with allergy. Nature 2007, 447, 92-96. [CrossRef] [PubMed]

41. Sheldon, K.E.; Shandilya, H.; Kepka-Lenhart, D.; Poljakovic, M.; Ghosh, A.; Morris, S.M. Shaping the murine mMacrophage phenotype: IL-4 and cyclic AMP synergistically activate the arginase I Promoter. J. Immunol. 2013, 191, 2290-2298. [CrossRef]

42. Lv, R.; Bao, Q.; Li, Y. Regulation of M1-type and M2-type macrophage polarization in RAW264.7 cells by galectin-9. Mol. Med. Rep. 2017, 16, 9111-9119. [CrossRef] [PubMed]

43. Wang, J.; Kubes, P. A reservoir of mature cavity macrophages that can rapidly invade visceral Organs to affect tissue repair. Cell 2016, 165, 668-678. [CrossRef] [PubMed]

44. Hesketh, M.; Sahin, K.B.; West, Z.E.; Murray, R.Z. Macrophage phenotypes regulate scar formation and chronic wound healing. Int. J. Mol. Sci. 2017, 18, 1545. [CrossRef]

45. Guilliams, M.; Mildner, A.; Yona, S. Developmental and functional heterogeneity of monocytes. Immunity 2018, 49, 595-613. [CrossRef] [PubMed]

46. Shi, C.; Pamer, E.G. Monocyte recruitment during infection and inflammation. Nat. Rev. Immunol. 2011, 11, 762-774. [CrossRef]

47. Flannagan, R.S.; Jaumouillé, V.; Grinstein, S. The cell biology of phagocytosis. Annu. Rev. Pathol. Mech. Dis. 2012, 7, 61-98. [CrossRef]

48. Plüddemann, A.; Mukhopadhyay, S.; Gordon, S. Innate immunity to intracellular pathogens: Macrophage receptors and responses to microbial entry. Immunol. Rev. 2011, 240, 11-24. [CrossRef]

49. Rosales, C.; Uribe-Querol, E. Phagocytosis: A fundamental process in immunity. Biomed Res. Int. 2017, 2017, e9042851. [CrossRef]

50. Taylor, P.; Martinez-Pomares, L.; Stacey, M.; Lin, H.H.; Brown, G.; Gordon, S. Macrophage receptors and immune recognition. Annu. Rev. Immunol. 2004, 23, 901-944. [CrossRef]

51. Licona-Limón, I.; Garay-Canales, C.A.; Muñoz-Paleta, O.; Ortega, E. CD13 mediates phagocytosis in human monocytic cells. J. Leukoc. Biol. 2015, 98, 85-98. [CrossRef]

52. Kubelkova, K.; Macela, A. Innate immune recognition: An issue more complex than expected. Front. Cell. Infect. Microbiol. 2019, 9. [CrossRef] 
53. Negrini, T.d.C.; Ferreira, L.S.; Alegranci, P.; Arthur, R.A.; Sundfeld, P.P.; Maia, D.C.G.; Spolidorio, L.C.; Carlos, I.Z. Role of TLR-2 and fungal surface antigens on innate immune response against Sporothrix schenckii. Immunol. Investig. 2013, 42, 36-48. [CrossRef]

54. Barreto-Bergter, E.; Figueiredo, R.T. Fungal glycans and the innate immune recognition. Front. Cell. Infect. Microbiol. 2014, 4. [CrossRef]

55. Patin, E.C.; Thompson, A.; Orr, S.J. Pattern recognition receptors in fungal immunity. Semin. Cell Dev. Biol. 2019, 89, 24-33. [CrossRef]

56. Negrini, T.d.C.; Arthur, R.A.; Carlos, I.Z. Recent advances on the role of Toll-like receptors in sporotrichosis-An overview. Microbiol. Res. J. Int. 2016, 1-10. [CrossRef]

57. Mukherjee, S.; Karmakar, S.; Babu, S.P.S. TLR2 and TLR4 mediated host immune responses in major infectious diseases: A review. Braz. J. Infect. Dis. 2016, 20, 193-204. [CrossRef]

58. Sassá, M.F.; Saturi, A.E.T.; Souza, L.F.; Ribeiro, L.C.D.A.; Sgarbi, D.B.D.G.; Carlos, I.Z. Response of macrophage Toll-like receptor 4 to a Sporothrix schenckii lipid extract during experimental sporotrichosis. Immunology 2009, 128, 301-309. [CrossRef]

59. Rossato, L.; Santos, S.S.d.; Ferreira, L.G.; de Almeida, S.R. The importance of Toll-like receptor 4 during experimental Sporothrix brasiliensis infection. Med Mycol. 2019, 57, 489-495. [CrossRef]

60. Sassá, M.F.; Ferreira, L.S.; de Abreu Ribeiro, L.C.; Carlos, I.Z. Immune response against Sporothrix schenckii in TLR-4-deficient mice. Mycopathologia 2012, 174, 21-30. [CrossRef] [PubMed]

61. Negrini, T.d.C.; Ferreira, L.S.; Arthur, R.A.; Alegranci, P.; Placeres, M.C.P.; Spolidorio, L.C.; Carlos, I.Z. Influence of TLR-2 in the immune response in the infection induced by fungus Sporothrix schenckii. Immunol. Investig. 2014, 43, 370-390. [CrossRef] [PubMed]

62. Flores-García, A.; Velarde-Félix, J.S.; Garibaldi-Becerra, V.; Rangel-Villalobos, H.; Torres-Bugarín, O.; Zepeda-Carrillo, E.A.; Ruíz-Bernés, S.; Ochoa-Ramírez, L.A. Recombinant murine IL-12 promotes a protective Th1/cellular response in Mongolian gerbils infected with Sporothrix schenckii. J. Chemother. 2015, 27, 87-93. [CrossRef] [PubMed]

63. Maia, D.C.G.; Sassá, M.F.; Placeres, M.C.P.; Carlos, I.Z. Influence of Th1/Th2 cytokines and nitric oxide in murine systemic infection induced by Sporothrix schenckii. Mycopathologia 2006, 161, 11-19. [CrossRef]

64. Carlos, I.Z.; Sassá, M.F.; da Graça Sgarbi, D.B.; Placeres, M.C.P.; Maia, D.C.G. Current research on the immune response to experimental sporotrichosis. Mycopathologia 2009, 168,1-10. [CrossRef]

65. Sollberger, G.; Strittmatter, G.E.; Garstkiewicz, M.; Sand, J.; Beer, H.D. Caspase-1: The inflammasome and beyond. Innate Immun. 2014, 20, 115-125. [CrossRef]

66. Yang, Y.; Wang, H.; Kouadir, M.; Song, H.; Shi, F. Recent advances in the mechanisms of NLRP3 inflammasome activation and its inhibitors. Cell Death Dis. 2019, 10,1-11. [CrossRef]

67. Gonçalves, A.C.; Ferreira, L.S.; Manente, F.A.; Faria, C.M.Q.G.D.; Polesi, M.C.; Andrade, C.R.d.; Zamboni, D.S.; Carlos, I.Z. The NLRP3 inflammasome contributes to host protection during Sporothrix schenckii infection. Immunology 2017, 151, 154-166. [CrossRef]

68. Brown, G.D.; Taylor, P.R.; Reid, D.M.; Willment, J.A.; Williams, D.L.; Martinez-Pomares, L.; Wong, S.Y.; Gordon, S. Dectin-1 is a major $\beta$-Glucan receptor on macrophages. J. Exp. Med. 2002, 196, 407-412. [CrossRef]

69. Plato, A.; Hardison, S.E.; Brown, G.D. Pattern recognition receptors in antifungal immunity. Semin. Immunopathol. 2015, 37, 97-106. [CrossRef]

70. Jellmayer, J.A.; Ferreira, L.S.; Manente, F.A.; Gonçalves, A.C.; Polesi, M.C.; Batista-Duharte, A.; Carlos, I.Z. Dectin-1 expression by macrophages and related antifungal mechanisms in a murine model of Sporothrix schenckii sensu stricto systemic infection. Microb. Pathog. 2017, 110, 78-84. [CrossRef]

71. Pavón Romero, L.; Jiménez Martínez, M.d.C.; Garcés Álvarez, M.E. Inmunología Molecular, Celular y Traslacional; Wolters Kluwer: Barcelona, España, 2020.

72. Koenderman, L.; Buurman, W.; Daha, M.R. The innate immune response. Immunol. Lett. 2014, 162, 95-102. [CrossRef]

73. Kajiwara, H.; Saito, M.; Ohga, S.; Uenotsuchi, T.; Yoshida, S.i. Impaired host defense against Sporothrix schenckii in mice with chronic granulomatous disease. Infect. Immun. 2004, 72, 5073-5079. [CrossRef] [PubMed]

74. Shiraishi, A.; Nakagaki, K.; Arai, T. Experimental sporotrichosis in congenitally athymic (nude) mice. J. Reticuloendothel. Soc. 1979, 26, 333-336. [PubMed]

75. Dickerson, C.L.; Taylor, R.L.; Drutz, D.J. Susceptibility of congenitally athymic (nude) mice to sporotrichosis. Infect. Immun. 1983, 40, 417-420. [CrossRef]

76. Shiraishi, A.; Nakagaki, K.; Arai, T. Role of cell-mediated immunity in the resistance to experimental sporotrichosis in mice. Mycopathologia 1992, 120, 15-21. [CrossRef] [PubMed]

77. Tachibana, T.; Matsuyama, T.; Mitsuyama, M. Involvement of CD4+ T cells and macrophages in acquired protection against infection with Sporothrix schenckii in mice. Med Mycol. 1999, 37, 397-404. [CrossRef]

78. Carlos, I.Z.; da Graca Sgarbi, D.B.; Angluster, J.; Alviano, C.S.; Silva, C.L. Detection of cellular immunity with the soluble antigen of the fungus Sporothrix schenckii in the systemic form of the disease. Mycopathologia 1992, 117, 139-144. [CrossRef]

79. Carlos, I.Z.; Sgarbi, D.B.d.g.; Placeres, M.C.P. Host organism defense by a peptide-polysaccharide extracted from the fungus Sporothrix schenckii. Mycopathologia 1998, 144, 9-14. [CrossRef] 
80. Verdan, F.F.; Faleiros, J.C.; Ferreira, L.S.; Monnazzi, L.G.S.; Maia, D.C.G.; Tansine, A.; Placeres, M.C.P.; Carlos, I.Z.; Santos-Junior, R.R. Dendritic cell are able to differentially recognize Sporothrix schenckii antigens and promote Th1/Th17 response in vitro. Immunobiology 2012, 217, 788-794. [CrossRef]

81. Ferreira, L.S.; Gonçalves, A.C.; Portuondo, D.L.; Maia, D.C.G.; Placeres, M.C.P.; Batista-Duharte, A.; Carlos, I.Z. Optimal clearance of Sporothrix schenckii requires an intact Th17 response in a mouse model of systemic infection. Immunobiology 2015, 220, 985-992. [CrossRef]

82. Maia, D.C.G.; Gonçalves, A.C.; Ferreira, L.S.; Manente, F.A.; Portuondo, D.L.; Vellosa, J.C.R.; Polesi, M.C.; Batista-Duharte, A.; Carlos, I.Z. Response of cytokines and hydrogen peroxide to Sporothrix schenkii exoantigen in systemic experimental infection. Mycopathologia 2016, 181, 207-215. [CrossRef]

83. Alegranci, P.; de Abreu Ribeiro, L.C.; Ferreira, L.S.; Negrini, T.d.C.; Maia, D.C.G.; Tansini, A.; Gonçalves, A.C.; Placeres, M.C.P.; Carlos, I.Z. The predominance of alternatively activated macrophages following challenge with cell wall peptide-polysaccharide after prior infection with Sporothrix schenckii. Mycopathologia 2013, 176, 57-65. [CrossRef] [PubMed]

84. Garcia, B.M.; Bond, A.R.; Barry, A.K.; Steen, A.J.; LeBoit, P.E.; Ashbaugh, C.; Shinkai, K. Disseminated-cutaneous sporotrichosis in an immunocompetent adult. JAAD Case Rep. 2021, 11, 102-104. [CrossRef] [PubMed]

85. Conceição-Silva, F.; Morgado, F.N. Immunopathogenesis of human Sporotrichosis: What we already know. J. Fungi 2018, 4, 89. [CrossRef] [PubMed]

86. Fernandes, K.S.S.; Coelho, A.L.J.; Bezerra, L.M.L.; Barja-Fidalgo, C. Virulence of Sporothrix schenckii conidia and yeast cells, and their susceptibility to nitric oxide. Immunology 2000, 101, 563-569. [CrossRef]

87. Fernandes, K.S.S.; Neto, E.H.; Brito, M.M.S.; Silva, J.S.; Cunha, F.Q.; Barja-Fidalgo, C. Detrimental role of endogenous nitric oxide in host defence against Sporothrix schenckii. Immunology 2008, 123, 469-479. [CrossRef] [PubMed]

88. Morgado, F.N.; Schubach, A.O.; Barros, M.B.L.; Conceição-Silva, F. The in situ inflammatory profile of lymphocutaneous and fixed forms of human sporotrichosis. Med Mycol. 2011, 49, 612-620. [CrossRef]

89. Brito, M.M.S.; Conceição-Silva, F.; Morgado, F.N.; Raibolt, P.S.; Schubach, A.; Schubach, T.P.; Schäffer, G.M.V.; Borba, C.M. Comparison of virulence of different Sporothrix schnckii clinical isolates using experimental murine model. Med Mycol. 2007, 45, 721-729. [CrossRef]

90. Uenotsuchi, T.; Takeuchi, S.; Matsuda, T.; Urabe, K.; Koga, T.; Uchi, H.; Nakahara, T.; Fukagawa, S.; Kawasaki, M.; Kajiwara, H.; et al. Differential induction of Th1-prone immunity by human dendritic cells activated with Sporothrix schenkii of cutaneous and visceral origins to determine their different virulence. Int. Immunol. 2006, 18, 1637-1646. [CrossRef]

91. Morgado, F.N.; de Carvalho, L.M.V.; Leite-Silva, J.; Seba, A.J.; Pimentel, M.I.F.; Fagundes, A.; Madeira, M.F.; Lyra, M.R.; Oliveira, M.M.; Schubach, A.O.; et al. Unbalanced inflammatory reaction could increase tissue destruction and worsen skin infectious diseases-A comparative study of leishmaniasis and sporotrichosis. Sci. Rep. 2018, 8, 2898. [CrossRef] [PubMed]

92. Wynn, T.A.; Barron, L. Macrophages: Master regulators of inflammation and fibrosis. Semin. Liver Dis. 2010, 30, $245-257$. [CrossRef]

93. Quintella, L.P.; Passos, S.R.L.; Vale, A.C.F.D.; Galhardo, M.C.G.; Barros, M.B.D.L.; Cuzzi, T.; Reis, R.D.S.; Carvalho, M.H.G.F.D.; Zappa, M.B.; Schubach, A.D.O. Histopathology of cutaneous sporotrichosis in Rio de Janeiro: A series of 119 consecutive cases. J. Cutan. Pathol. 2011, 38, 25-32. [CrossRef]

94. Guzman-Beltran, S.; Perez-Torres, A.; Coronel-Cruz, C.; Torres-Guerrero, H. Phagocytic receptors on macrophages distinguish between different Sporothrix schenckii morphotypes. Microbes Infect. 2012, 14, 1093-1101. [CrossRef]

95. Guzman Beltrán, S.; Sanchez Morales, J.; González Canto, A.; Escalona Montaño, A.; Torres Guerrero, H. Human serum proteins bind to Sporothrix schenckii conidia with differential effects on phagocytosis. Braz. J. Microbiol. 2021, 52, 33-39. [CrossRef]

96. Hind, C.R.K.; Collins, P.M.; Baltz, M.L.; Pepys, M.B. Human serum amyloid P component, a circulating lectin with specificity for the cyclic 4,6-pyruvate acetal of galactose. Interactions with various bacteria. Biochem. J. 1985, 225, 107-111. [CrossRef]

97. Yuste, J.; Botto, M.; Bottoms, S.E.; Brown, J.S. Serum amyloid P aids complement-mediated immunity to Streptococcus pneumoniae. PLoS Pathog. 2007, 3, e120. [CrossRef]

98. Noursadeghi, M.; Bickerstaff, M.C.M.; Gallimore, J.R.; Herbert, J.; Cohen, J.; Pepys, M.B. Role of serum amyloid P component in bacterial infection: protection of the host or protection of the pathogen. Proc. Natl. Acad. Sci. USA 2000, 97, 14584-14589. [CrossRef]

99. Haas, C.J.C.d.; Leeuwen, E.M.M.V.; Bommel, T.V.; Verhoef, J.; Kessel, K.P.M.V.; Strijp, J.A.G.V. Serum amyloid P component bound to Gram-negative bacteria prevents lipopolysaccharide-mediated classical pathway complement activation. Infect. Immun. 2000, 68, 1753-1759. [CrossRef]

100. Klotz, S.A.; Sobonya, R.E.; Lipke, P.N.; Garcia-Sherman, M.C. Serum amyloid P component and systemic fungal infection: Does it protect the host or is it a trojan Horse? Open Forum Infect. Dis. 2016, 3. [CrossRef]

101. Gilchrist, K.B.; Garcia, M.C.; Sobonya, R.; Lipke, P.N.; Klotz, S.A. New features of invasive candidiasis in humans: Amyloid formation by fungi and deposition of serum amyloid P component by the host. J. Infect. Dis. 2012, 206, 1473-1478. [CrossRef]

102. Garcia-Sherman, M.C.; Lundberg, T.; Sobonya, R.E.; Lipke, P.N.; Klotz, S.A. A unique biofilm in human deep mycoses: Fungal amyloid is bound by host serum amyloid P component. Npj Biofilms Microbiomes 2015, 1, 1-4. [CrossRef]

103. Behrens, N.E.; Lipke, P.N.; Pilling, D.; Gomer, R.H.; Klotz, S.A. Serum amyloid P component binds fungal surface amyloid and decreases human macrophage phagocytosis and secretion of inflammatory cytokines. mBio 2019, 10. [CrossRef] [PubMed] 
104. Bergin, D.A.; Hurley, K.; McElvaney, N.G.; Reeves, E.P. Alpha-1 antitrypsin: A potent anti-inflammatory and potential novel therapeutic agent. Arch. Immunol. Ther. Exp. 2012, 60, 81-97. [CrossRef] [PubMed]

105. Bergin, D.A.; Reeves, E.P.; Meleady, P.; Henry, M.; McElvaney, O.J.; Carroll, T.P.; Condron, C.; Chotirmall, S.H.; Clynes, M.; O'Neill, S.J.; et al. $\alpha-1$ Antitrypsin regulates human neutrophil chemotaxis induced by soluble immune complexes and IL-8. J. Clin. Investig. 2010, 120, 4236-4250. [CrossRef]

106. Agné, A.; Richter, K.; Padberg, W.; Janciauskiene, S.; Grau, V. Commercial $\alpha 1$-antitrypsin preparations markedly differ in their potential to inhibit the ATP-induced release of monocytic interleukin-1 $\beta$. Pulm. Pharmacol. Ther. 2021, 68, 102020. [CrossRef]

107. Zhou, Z.; Xu, M.J.; Gao, B. Hepatocytes: A key cell type for innate immunity. Cell. Mol. Immunol. 2016, 13, 301-315. [CrossRef] [PubMed]

108. Valente, M.D.F.; Diogo, A.B.; Merlo, V.F.C.; Pegas, J.R.P.; Valente, M.d.F.; Diogo, A.B.; Merlo, V.F.C.; Pegas, J.R.P. Disseminated cutaneous sporotrichosis: unusual presentation in an alcoholic patient. Rev. Inst. Med. Trop. SãO Paulo 2020, 62. [CrossRef]

109. Benvegnú, A.M.; Stramari, J.; Dallazem, L.N.D.; Chemello, R.M.L.; Beber, A.A.C.; Benvegnú, A.M.; Stramari, J.; Dallazem, L.N.D.; Chemello, R.M.L.; Beber, A.A.C. Disseminated cutaneous sporotrichosis in patient with alcoholism. Rev. Soc. Bras. Med. Trop. 2017, 50, 871-873. [CrossRef]

110. Nassif, P.W.; Granado, I.R.M.d.O.; Ferraz, J.S.; Souza, R.; Nassif, A.E. Esporotricose cutânea de apresentação atípica em paciente etilista. Dermatol. Online J. 2012, 18, 12. [CrossRef]

111. Yang, C.Y.; Chen, J.B.; Tsai, T.F.; Tsai, Y.C.; Tsai, C.Y.; Liang, P.H.; Hsu, T.L.; Wu, C.Y.; Netea, M.G.; Wong, C.H.; et al. CLEC4F is an iducible C-type lectin in F4/80-positive cells and is involved in alpha-galactosylceramide presentation in liver. PLoS ONE 2013, 8, e65070. [CrossRef]

112. Martinez-Pomares, L. The mannose receptor. J. Leukoc. Biol. 2012, 92, 1177-1186. [CrossRef]

113. Józefowski, S.; Yang, Z.; Marcinkiewicz, J.; Kobzik, L. Scavenger receptors and $\beta$-glucan receptors participate in the recognition of yeasts by murine macrophages. Inflamm. Res. 2012, 61, 113-126. [CrossRef]

114. Dantzer, R.; O'Connor, J.C.; Freund, G.G.; Johnson, R.W.; Kelley, K.W. From inflammation to sickness and depression: When the immune system subjugates the brain. Nat. Rev. Neurosci. 2008, 9, 46-56. [CrossRef]

115. Øverland, G.; Stuestøl, J.F.; Dahle, M.K.; Myhre, A.E.; Netea, M.G.; Verweij, P.; Yndestad, A.; Aukrust, P.; Kullberg, B.J.; Warris, A.; et al. Cytokine responses to fungal pathogens in Kupffer cells are Toll-like receptor 4 independent and mediated by tyrosine kinases. Scand. J. Immunol. 2005, 62, 148-154. [CrossRef] [PubMed]

116. Okabe, Y.; Medzhitov, R. Tissue biology perspective on macrophages. Nat. Immunol. 2016, 17, 9-17. [CrossRef]

117. Rosas, M.; Davies, L.C.; Giles, P.J.; Liao, C.T.; Kharfan, B.; Stone, T.C.; O’Donnell, V.B.; Fraser, D.J.; Jones, S.A.; Taylor, P.R. The transcription factor Gata6 links tissue macrophage phenotype and proliferative renewal. Science 2014, 344, 645-648. [CrossRef]

118. A-Gonzalez, N.; Quintana, J.A.; García-Silva, S.; Mazariegos, M.; González de la Aleja, A.; Nicolás-Ávila, J.A.; Walter, W.; Adrover, J.M.; Crainiciuc, G.; Kuchroo, V.K.; et al. Phagocytosis imprints heterogeneity in tissue-resident macrophages. J. Exp. Med. 2017, 214, 1281-1296. [CrossRef]

119. Gautier, E.L.; Shay, T.; Miller, J.; Greter, M.; Jakubzick, C.; Ivanov, S.; Helft, J.; Chow, A.; Elpek, K.G.; Gordonov, S.; et al. Geneexpression profiles and transcriptional regulatory pathways that underlie the identity and diversity of mouse tissue macrophages. Nat. Immunol. 2012, 13, 1118-1128. [CrossRef]

120. Lavin, Y.; Winter, D.; Blecher-Gonen, R.; David, E.; Keren-Shaul, H.; Merad, M.; Jung, S.; Amit, I. Tissue-resident macrophage enhancer landscapes are shaped by the local microenvironment. Cell 2014, 159, 1312-1326. [CrossRef]

121. Rückerl, D.; Campbell, S.M.; Duncan, S.; Sutherland, T.E.; Jenkins, S.J.; Hewitson, J.P.; Barr, T.A.; Jackson-Jones, L.H.; Maizels, R.M.; Allen, J.E. Macrophage origin limits functional plasticity in helminth-bacterial co-infection. PLoS Pathog. 2017, 13, e1006233. [CrossRef]

122. Lee, S.H.; Charmoy, M.; Romano, A.; Paun, A.; Chaves, M.M.; Cope, F.O.; Ralph, D.A.; Sacks, D.L. Mannose receptor high, M2 dermal macrophages mediate nonhealing Leishmania major infection in a Th1 immune environment. J. Exp. Med. 2017, 215, 357-375. [CrossRef]

123. Lee, S.H.; Chaves, M.M.; Kamenyeva, O.; Gazzinelli-Guimaraes, P.H.; Kang, B.; Pessenda, G.; Passelli, K.; Tacchini-Cottier, F.; Kabat, J.; Jacobsen, E.A.; et al. M2-like, dermal macrophages are maintained via IL-4/CCL24-mediated cooperative interaction with eosinophils in cutaneous leishmaniasis. Sci. Immunol. 2020, 5. [CrossRef] [PubMed]

124. Murray, P.; Allen, J.; Biswas, S.; Fisher, E.; Gilroy, D.; Goerdt, S.; Gordon, S.; Hamilton, J.; Ivashkiv, L.; Lawrence, T.; et al. Macrophage activation and polarization: Nomenclature and experimental guidelines. Immunity 2014, 41, 14-20. [CrossRef] [PubMed]

125. Jenkins, S.J.; Ruckerl, D.; Cook, P.C.; Jones, L.H.; Finkelman, F.D.; Rooijen, N.V.; MacDonald, A.S.; Allen, J.E. Local macrophage proliferation, rather than recruitment from the blood, is a signature of TH2 inflammation. Science 2011, 332, 1284-1288. [CrossRef]

126. Schleicher, U.; Paduch, K.; Debus, A.; Obermeyer, S.; König, T.; Kling, J.C.; Ribechini, E.; Dudziak, D.; Mougiakakos, D.; Murray, P.J.; et al. TNF-mediated restriction of arginase 1 expression in myeloid cells triggers type 2 NO synthase activity at the site of infection. Cell Rep. 2016, 15, 1062-1075. [CrossRef] [PubMed]

127. Casadevall, A.; Pirofski, L.a. Host-pathogen interactions: redefining the basic concepts of virulence and pathogenicity. Infect. Immun. 1999, 67, 3703-3713. [CrossRef]

128. Casadevall, A.; Pirofski, L. Host-pathogen interactions: The attributes of virulence. J. Infect. Dis. 2001, 184, 337-344. [CrossRef] [PubMed] 
129. Casadevall, A.; Pirofski, L.A. The damage-response framework of microbial pathogenesis. Nat. Rev. Microbiol. $2003,1,17-24$. [CrossRef]

130. Nemecek, J.C.; Wüthrich, M.; Klein, B.S. Global control of dimorphism and virulence in fungi. Science 2006, 312, 583-588. [CrossRef] [PubMed]

131. Gauthier, G.; Klein, B.S. Insights into fungal morphogenesis and immune evasion. Microbe 2008, 3, 416-423. [CrossRef] [PubMed]

132. Sgarbi, D.B.; da Silva, A.J.R.; Carlos, I.Z.; Silva, C.L.; Angluster, J.; Alviano, C.S. Isolation of ergosterol peroxide and its reversion to ergosterol in the pathogenic fungus Sporothrix schenckii. Mycopathologia 1997, 139, 9. [CrossRef]

133. Brilhante, R.S.; Pereira, V.S.; Oliveira, J.S.; Rodrigues, A.M.; de Camargo, Z.P.; Pereira-Neto, W.A.; Nascimento, N.R.; CasteloBranco, D.S.; Cordeiro, R.A.; Sidrim, J.J.; et al. Terpinen-4-ol inhibits the growth of Sporothrix schenckii complex and exhibits synergism with antifungal agents. Future Microbiol. 2019, 14, 1221-1233. [CrossRef]

134. Borba-Santos, L.P.; Visbal, G.; Gagini, T.; Rodrigues, A.M.; de Camargo, Z.P.; Lopes-Bezerra, L.M.; Ishida, K.; de Souza, W.; Rozental, S. $\Delta 24$-sterol Methyltransferase plays an important role in the growth and development of Sporothrix schenckii and Sporothrix brasiliensis. Front. Microbiol. 2016, 7. [CrossRef]

135. Romero-Martinez, R.; Wheeler, M.; Guerrero-Plata, A.; Rico, G.; Torres-Guerrero, H. Biosynthesis and functions of melanin in Sporothrix schenckii. Infect. Immun. 2000, 68, 3696-3703. [CrossRef] [PubMed]

136. Almeida-Paes, R.; Figueiredo-Carvalho, M.H.G.; Brito-Santos, F.; Almeida-Silva, F.; Oliveira, M.M.E.; Zancopé-Oliveira, R.M. Melanins protect Sporothrix brasiliensis and Sporothrix schenckii from the antifungal effects of terbinafine. PLoS ONE 2016, 11, e0152796. [CrossRef] [PubMed]

137. Mario, D.A.N.; Santos, R.C.V.; Denardi, L.B.; Vaucher, R.d.A.; Santurio, J.M.; Alves, S.H. Interference of melanin in the susceptibility profile of Sporothrix species to amphotericin B. Rev. Iberoam. Micol. 2016, 33, 21-25. [CrossRef]

138. Madrid, I.M.; Xavier, M.O.; Mattei, A.S.; Fernandes, C.G.; Guim, T.N.; Santin, R.; Schuch, L.F.D.; Nobre, M.D.O.; Araújo Meireles, M.C. Role of melanin in the pathogenesis of cutaneous sporotrichosis. Microbes Infect. 2010, 12, 162-165. [CrossRef] [PubMed]

139. Oda, L.M.; Kubelka, C.F.; Alviano, C.S.; Travassos, L.R. Ingestion of yeast forms of Sporothrix schenckii by mouse peritoneal macrophages. Infect. Immun. 1983, 39, 497-504. [CrossRef]

140. Alviano, C.S.; Pereira, M.E.A.; Souza, W.; Oda, L.M.; Travassos, L.R. Sialic acids are surface components of Sporothrix schenckii yeast forms. FEMS Microbiol. Lett. 1982, 15, 223-227. [CrossRef]

141. Carlos, I.Z.; Sgarbi, D.B.G.; Santos, G.C.; Placeres, M.C.P. Sporothrix schenckii lipid inhibits macrophage phagocytosis: Involvement of nitric oxide and tumour necrosis factor- $\alpha$. Scand. J. Immunol. 2003, 57, 214-220. [CrossRef]

142. Gonçalves, A.C.; Maia, D.C.G.; Ferreira, L.S.; Monnazzi, L.G.S.; Alegranci, P.; Placeres, M.C.P.; Batista-Duharte, A.; Carlos, I.Z. Involvement of major components from Sporothrix schenckii cell wall in the caspase-1 activation, nitric oxide and cytokines production during experimental sporotrichosis. Mycopathologia 2015, 179, 21-30. [CrossRef]

143. Garrison, R.G.; Arnold, W.N. Cytochemical localization of acid phosphatases in the dimorphic fungus Sporothrix schenckii. Curr. Microbiol. 1983, 9, 253-257. [CrossRef]

144. Hogan, L.H.; Klein, B.S.; Levitz, S.M. Virulence factors of medically important fungi. Clin. Microbiol. Rev. 1996, 9, 469-488. [CrossRef] [PubMed] 